\title{
Preliminary results of an orchid survey of New Britain, Papua New Guinea: five new species of Bulbophyllum (Orchidaceae)
}

\author{
J.J. Vermeulen' ${ }^{1}$, E.F. de Vogel $^{1}$, A.P.T.M. Vogel ${ }^{2}$
}

\section{Key words}

Bismarck Archipelago

Bulbophyllum

New Britain

Orchidaceae

Papua New Guinea
Abstract Five new species of Bulbophyllum, originating from New Britain in the Bismarck Archipelago, Papua New Guinea, are described.

Published on 9 December 2010

\section{INTRODUCTION}

Surveys of the orchid flora of the island of New Britain in the Bismarck Archipelago, Papua New Guinea, carried out by the second author have yielded some 1200 living collections, possibly representing some 300 different species. These are in cultivation at the National Capital Botanical Garden in Port Moresby, Papua New Guinea, and at Leiden Botanical Gardens in The Netherlands. Although Bulbophyllum is less well represented in this collection than in similar collections from mainland Papua New Guinea, some 25 different species have flowered so far. Five of these have proven to be new to science and are described below.

Bulbophyllum drepananthum J.J.Verm., de Vogel \& A.Vogel, sp. nov. (section Hoplandra) - Fig. 1

A Bulbophyllo contortisepalo et $B$. falcifero sepalis lateralibus subacutis nec acuminatis aut caudatis differt. - Typus: LEI 20080322 (holo LAE; iso L), Papua New Guinea, West New Britain, Asengseng logging area, Upper Au River.

Roots emerging scattered along the rhizome. Rhizome creeping, to $1.8 \mathrm{~mm}$ diam, sections between pseudobulbs up to 0.9 $\mathrm{cm}$ long, bracts usually not persistent. Pseudobulbs ovoid to ellipsoid, to 0.8 by $0.5 \mathrm{~cm}$. Leaf with petiole up to $1 \mathrm{~mm}$, blade elliptic, up to 1.3 by $0.9 \mathrm{~cm}$, index (length/width) $1.4-1.5$; subacute. Inflorescence c. $8 \mathrm{~cm}$ long, 1-flowered. Peduncle c. $4.5 \mathrm{~cm}$ long, bracts 4 , the longest c. $6 \mathrm{~mm}$ long. Floral bracts tubular at the base, c. $6 \mathrm{~mm}$, acute. Flowers not opening widely. Pedicel and ovary c. $14 \mathrm{~mm}$ long, basal node on a c. 2 mm-long stump. Median sepal porrect, laterally compressed and crested distally, ovate, c. 7.2 by $2.2 \mathrm{~mm}$, index c. 3.2 (all measured without flattening); acute, margins entire, base broadly attached; rather thick, glabrous. Lateral sepals porrect, oblique, slightly falcate, ovate, shortly clawed, c. 26 by $5 \mathrm{~mm}$, index c. 5.2, subacute, margins entire, base broadly attached; rather thick, glabrous. Petals porrect, ovate-triangular, c. 2.2

\footnotetext{
${ }^{1}$ Netherlands Centre for Biodiversity Naturalis (section NHN), Leiden University, P.O. Box 9514, 2300 RA Leiden, The Netherlands; corresponding author e-mail: vermeulen@nhn.leidenuniv.nl.

2 Hortus botanicus Leiden, Leiden University, P.O. Box 9516, 2300 RA, Leiden, The Netherlands.
}

by $0.6 \mathrm{~mm}$, index $3.6-3.7$; truncate with an aristate tip, margins entire; thin, glabrous. Lip recurved, ovate, c. 2 by $1 \mathrm{~mm}$, index c. 2 (all measured without flattening); obtuse, margins ciliate, thick; adaxially slightly concave proximally, median part thickened over almost the entire length of the lip, leaving a furrow close to each margin, surface pubescent proximally, papillose-pubescent distally; abaxially with a truncate median ridge. Column c. $2 \mathrm{~mm}$ long, stigma narrowly oblong, without a tooth at the base, column foot with a median callus near the tip. Stelidia slightly porrect, triangular, c. $0.2 \mathrm{~mm}$ long, subacute, with an antrorse, deltoid, obtuse tooth along the upper margin. Anther abaxially with a papillose crest, surface otherwise \pm glabrous, front margin drawn out into an inflated beak. Pollinia 2; ellipsoid, without appendage.

Colours - Median sepal whitish, with thick blackish purple veins. Lateral sepals purple, distally whitish spotted purple. Petals pale pink. Lip pale yellowish, ciliae white.

Habitat \& Ecology — Primary forest, 150-300 m asl.

Distribution - Papua New Guinea, New Britain.

Note - Within the section, it shares the ciliate lip and the distally 3-dentate petals with $B$. contortisepalum J.J.Sm. and B. falciferum J.J.Sm. It differs from both in having subacute, not acuminate or caudate lateral sepals.

\section{Bulbophyllum hengstumianum J.J.Verm., de Vogel \&} A.Vogel, sp. nov. (section Macrouris) - Fig. 2

A Bulbophyllo callichroma et $B$. chlorantho floribus minoribus (sepalis lateralibus c. $7.5 \mathrm{~mm}$ longis contra $10-46 \mathrm{~mm}$ longis), sepalo medio sine plicis secus costam differt. - Typus: LEI 20080232 (holo LAE; iso L), Papua New Guinea, West New Britain, Asengseng logging area, Upper Au River.

Roots tufted below each pseudobulb. Rhizome long-creeping, to $2 \mathrm{~mm}$ diam, sections between pseudobulbs up to $5.8 \mathrm{~cm}$ long, bracts persistent, slightly fibrous. Pseudobulbs flattened-ovoid, to \pm lenticular, to 0.7 by $1 \mathrm{~cm}$. Leaf with petiole up to $3 \mathrm{~mm}$, blade ovate, up to 4.3 by $2 \mathrm{~cm}$, index (length/width) 1.6-2.5; acute. Inflorescence c. $25 \mathrm{~cm}$ long, a lax c. 10-flowered raceme. Peduncle c. $15 \mathrm{~cm}$ long, bracts c. 4 , the longest c. $5 \mathrm{~mm}$ long. Rhachis somewhat nodding, c. $10 \mathrm{~cm}$ long. Floral bracts c. 3 $\mathrm{mm}$, acute. Flowers not opening widely. Pedicel and ovary 5-7 $\mathrm{mm}$ long, basal node on a c. $1 \mathrm{~mm}$-long stump. Median sepal free, almost porrect, without folds along the midvein, ovate, c. 6 by $3.5 \mathrm{~mm}$, index c. 1.7; acute, margins entire, base broadly

() 2010 Nationaal Herbarium Nederland

You are free to share - to copy, distribute and transmit the work, under the following conditions:

Attribution: $\quad$ You must attribute the work in the manner specified by the author or licensor (but not in any way that suggests that they endorse you or your use of the work).

Non-commercia:

You may not use this work for commercial purposes.

No derivative works: You may not alter, transform, or build upon this work.

For any reuse or distribution, you must make clear to others the license terms of this work, which can be found at http://creativecommons.org/licenses/by-nc-nd/3.0/legalcode. Any of the above conditions can be waived if you get permission from the copyright holder. Nothing in this license impairs or restricts the author's moral rights. 


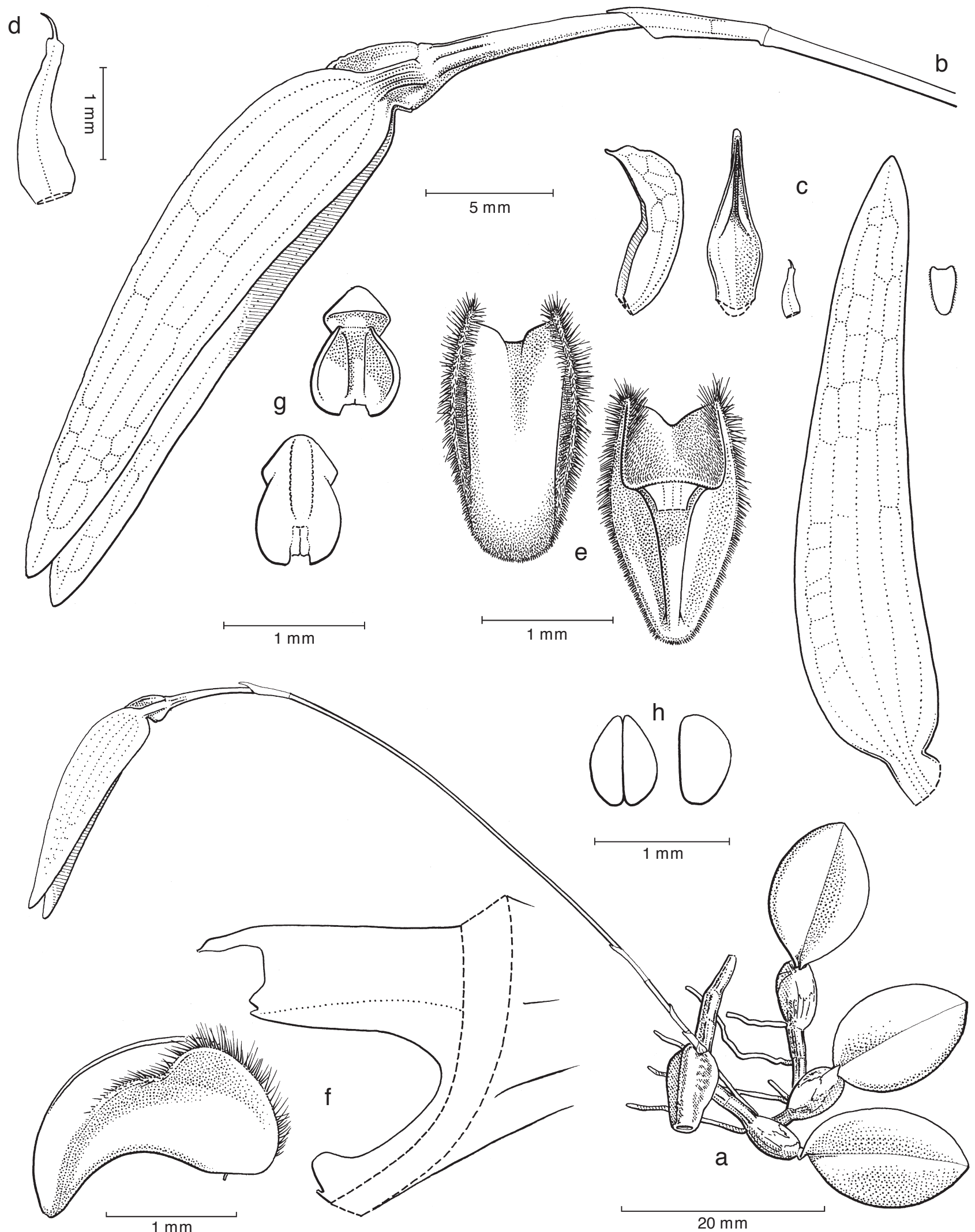

Fig. 1 Bulbophyllum drepananthum J.J.Verm., de Vogel \& A. Vogel. a. Habit; b. flower; c. flower analysis, from left to right: median sepal lateral view and adaxial view, petal, lateral sepal, lip; d. petal; e. lip, left: adaxial side, right: abaxial side; f. column and lip, lateral view; g. anther, above: adaxial side, below: abaxial side; h. pollinia, left: a pair, right: a single (all: LEI 20080322 (spirit sample)). — Drawn by J.J. Vermeulen, 2010.

attached; rather thin, glabrous. Lateral sepals as the median, but adnate along the lower margins, oblique, somewhat recurved, c. 7.5 by $3 \mathrm{~mm}$, index c. 2.5. Petals porrect, ovate-oblong, c. 2.5 by $2.1 \mathrm{~mm}$, index c. 1.2 ; margins entire; rather thin, glabrous. Lip recurved, ovate, c. 1.2 by $1 \mathrm{~mm}$, index c. 1.2 (all measured without flattening); rounded, margins finely papillose locally, thick, surface finely papillose locally; adaxially concave proximally, with two keels starting close to the margins, then converging until they merge into a median callus; abaxially with a short, truncate median ridge. Column c. $1 \mathrm{~mm}$ long, stigma elliptic, with a distinct tooth at the base, column foot without teeth near the tip. Stelidia slightly upwards falcate, triangular, c. $0.5 \mathrm{~mm}$ long, subacute, with a deltoid, obtuse tooth along the lower margin. Anther abaxially without a crest, surface \pm 



Fig. 2 Bulbophyllum hengstumianum J.J.Verm., de Vogel \& A.Vogel. a. Habit; b. flower; c. flower analysis, from left to right: median sepal, petal, lateral sepals, lip; d. lip, left: adaxial side, right: abaxial side; e. column and lip, lateral view; f. anther, left: adaxial side, right: abaxial side; g. pollinia, above: a single pair, below: two pairs (all: LEI 20080232 (spirit sample)). — Drawn by J.J. Vermeulen, 2010.

glabrous, front margin drawn out into a triangular, acute beak. Pollinia 4; ovoid, without appendage, the inner minute.

Eponymy - The species is named in honour of Drs. R.J.M. van Hengstum for being the fount of inspiration in realizing the Netherlands Centre of Biodiversity Naturalis.

Colours - Sepals red, yellowish towards the margins. Petals yellow, midvein red. Lip red, proximally yellow towards the margins.
Habitat \& Ecology — Primary forest, 250-275 m asl. Distribution - Papua New Guinea, New Britain.

Note - Shares the creeping habit combined with the adnate lateral sepals with $B$. callichroma Schltr. and B. chloranthum Schltr. It differs from both in having smaller flowers (lateral sepals c. $7.5 \mathrm{~mm}$ long vs $10-46 \mathrm{~mm}$ long), and in lacking folds alongside the midvein of the median sepal. 




Fig. 3 Bulbophyllum magnussonianum J.J.Verm., de Vogel \& A.Vogel. a. Habit; b. flower; c. flower analysis, from left to right: median sepal, petal, lateral sepal, lip; d. lip, above: adaxial side, below: abaxial side; e. column and lip, lateral view; f. top column with petal, lateral view; g. anther, above: abaxial side, below: adaxial side; h. pollinia, left: two pairs, right: a single pair (a: LEI 20081550; b-g: LEI 20081518 (spirit samples)). — Drawn by J.J. Vermeulen, 2009.

Bulbophyllum magnussonianum J.J.Verm., de Vogel \& A.Vogel, sp. nov. (section Brachypus) - Fig. 3

A Bulbophyllo stolleano sepalis brevioribus (10.5-11.5 mm longis contra c. 22 mm longis) petalis brevioribus columna paulo longiore differt. - Typus: LEI 20081518 (holo LAE; iso L), Papua New Guinea, East New Britain, Matong Concession, upper Rak Road.
Roots emerging scattered along the rhizome. Rhizome short, to $5 \mathrm{~mm}$ diam, sections between pseudobulbs up to $1 \mathrm{~cm}$ long, bracts including fibres somewhat persistent. Pseudobulbs ovoid, to 3 by $1.8 \mathrm{~cm}$. Leaf with petiole up to $2 \mathrm{~cm}$, blade ovate, up to 7 by $2.7 \mathrm{~cm}$, index (length/width) 2.2-3.2; acuminate. Inflorescence c. $4 \mathrm{~cm}$ long, 1-flowered. Peduncle c. $1.8 \mathrm{~cm}$ long, bracts 3 , the longest c. $7 \mathrm{~mm}$ long. Floral bracts tubular, 



Fig. 4 Bulbophyllum tindemansianum J.J.Verm., de Vogel \& A.Vogel. a. Habit; b. flower; c. flower analysis, above: petal; below from left to right: median sepal, lateral sepal, lip; d. lip, left: adaxial side, right: abaxial side; e. column and lip, lateral view; f. anther, left: adaxial side, right: abaxial side; g. pollinia, left: two pairs, right: a single pair (all: LEI 20081503 (spirit sample)). — Drawn by J.J. Vermeulen, 2010.

c. $8 \mathrm{~mm}$, acute. Flowers not opening widely. Pedicel and ovary c. $11 \mathrm{~mm}$ long, basal node on a c. $2.2 \mathrm{~mm}$-long stump. Median sepal recurved distally, ovate, c. 10.5 by $3.5 \mathrm{~mm}$, index c. 3; acute, margins entire, base broadly attached; rather thick, thick diatally, glabrous. Lateral sepals as the median but oblique, c. 11.5 by $4 \mathrm{~mm}$, index 2.8-2.9. Petals fused to the column at their very base, porrect, elliptic-ovate, c. 3 by $0.7 \mathrm{~mm}$, index c. 4.3; acute, margins entire; rather thin, glabrous. Lip recurved, ovate-triangular, c. 2.9 by $1.8 \mathrm{~mm}$, index 1.6, acute-apiculate, margins entire; thick, glabrous; adaxially slightly concave proximally, with 2 low ridges starting near the margins, then converging, slightly spreading again, converging and merging into a slight median swelling; abaxially with a rounded median ridge. Column c. $2.8 \mathrm{~mm}$ long, stigma elliptic, basal margin not protruding, column foot without teeth. Stelidia porrect, triangular, c. $1.2 \mathrm{~mm}$ long, acute, with a slight tooth along the upper 

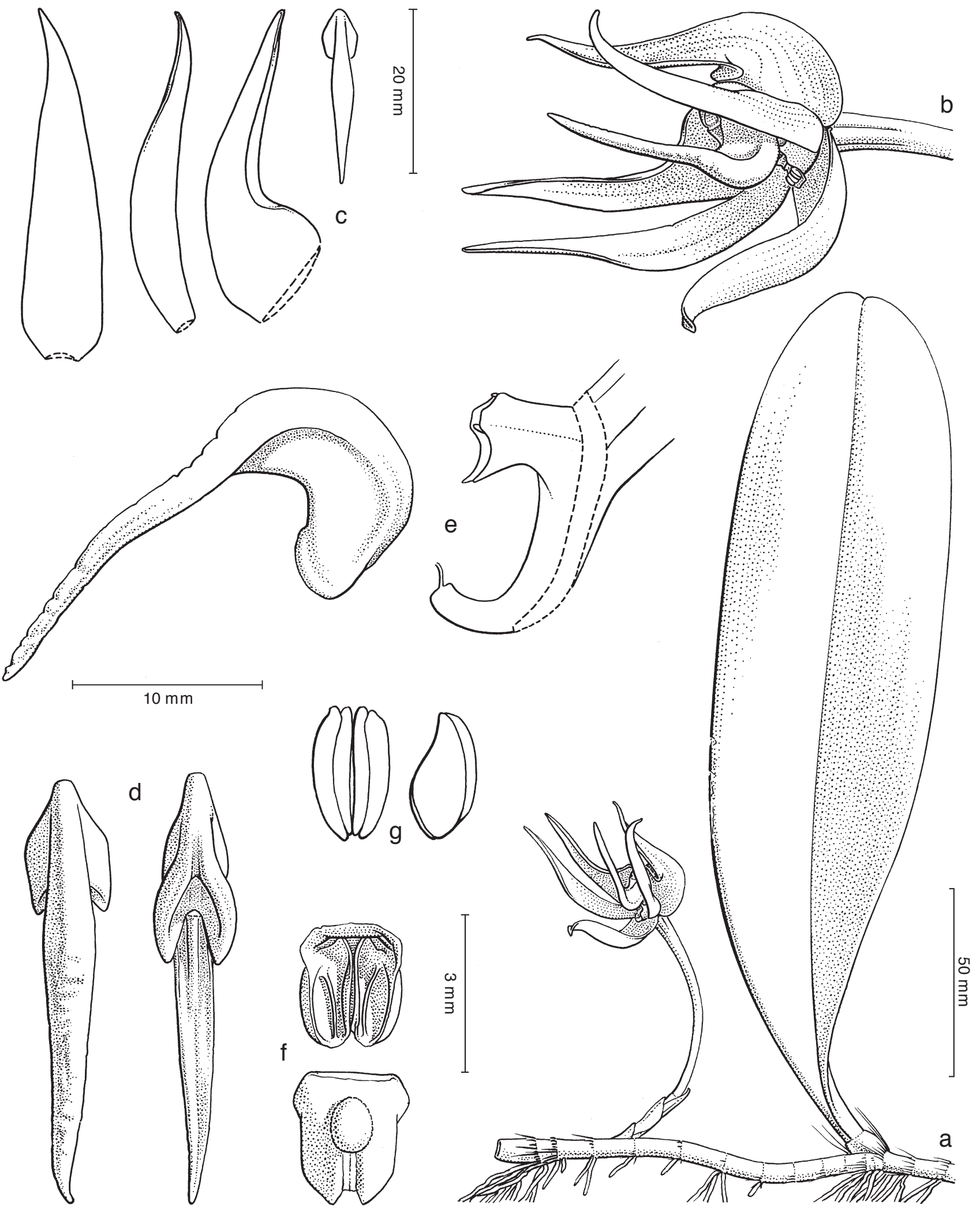

Fig. 5 Bulbophyllum xyphoglossum J.J.Verm., de Vogel \& A.Vogel. a. Habit; b. flower; c. flower analysis, from left to right: median sepal, petal, lateral sepals, lip; d. lip, left: adaxial side, right: abaxial side; e. column and lip, lateral view; f. anther, above: adaxial side, below: abaxial side; g. pollinia, left: two pairs, right: a single pair (all: LEI 20080243 (spirit sample)). — Drawn by J.J. Vermeulen, 2009.

margin. Anther abaxially with a wide papillose crest, surface otherwise \pm glabrous, front margin drawn out into a rounded beak. Pollinia $4 ; \pm$ rhomboid, without appendage, the inner almost as long as the outer.

Eponymy - Named after Hans Magnusson, Ambassador of Sweden in The Netherlands, in recognition of his stimulating role during the Linneaus tercentenary celebrations in 2007.

Colours - Flowers white.
Habitat \& Ecology - Primary forest, 20-30 m high, on limestone bedrock overlain by $1-2 \mathrm{~m}$ thick layer of red clayey soil, 650-850 $\mathrm{m}$ asl.

Distribution - Papua New Guinea, New Britain.

Note - Shares the simple lip morphology (without lateral lobes or distinct ridges on the adaxial side), in combination with the more or less lanceolate and acute petals with $B$. stolleanum Schltr. It differs in having shorter petals (not almost 
twice as long as the column), and in having shorter sepals (10.5-11.5 mm long vs c. $22 \mathrm{~mm}$ long). Several other species of section Brachypus have flowers of c. $1 \mathrm{~cm}$ long: $B$. galactanthum Schltr. has oblong petals and a lip $5 \mathrm{~mm}$ long; $B$. microlabium W.Kittr. has abaxially carinate petals; $B$. hans-meyeri J.J.Wood has obtuse sepals; $B$. rhomboglossum Schltr. has oblong petals.

\section{Bulbophyllum tindemansianum J.J.Verm., de Vogel \& A.Vogel, sp. nov. (section Epicrianthes) - Fig. 4}

In sectione Epicrianthes petalorum appendicibus modis 3 differentibus notata, a $B$. corrugato petalo latissimo appendice caudato gaudenti differt. - Typus: LEI 20081503 (holo LAE; iso L), Papua New Guinea, East New Britain, Matong Concession, upper Rak Road.

Roots: most emerging close to the base of the rhizome. Rhizome stiffly patent to pendulous, up to $15 \mathrm{~cm}$ long, 3-4 $\mathrm{mm}$ diam, sections between pseudobulbs up to $2 \mathrm{~cm}$ long, bracts persistent, fibrous. Pseudobulbs well spaced, obovoid, up to 1 by $0.5 \mathrm{~cm}$. Leaf subsessile, ovate, $4-7$ by $1.6-2.3 \mathrm{~cm}$, index (length/width) 2.5-3.2; subacute, abaxially rugose. Inflorescence c. $2.5 \mathrm{~cm}$ long, 1 -flowered. Peduncle c. $0.7 \mathrm{~cm}$ long, bracts 3 , the longest c. $4 \mathrm{~mm}$ long. Floral bracts tubular at the base, c. $5 \mathrm{~mm}$, acute. Flowers opening widely. Pedicel and ovary c. $11 \mathrm{~mm}$ long, basal node on a c. $6 \mathrm{~mm}$-long stump. Median sepal spreading, elliptic-ovate, c. 10 by $5.5 \mathrm{~mm}$, index 1.8; acute-apiculate, margins entire, base broadly attached; thick, glabrous. Lateral sepals as the median, but c. 10 by 6 $\mathrm{mm}$, index 1.6-1.7. Petals porrect, \pm lyriform, c. 1.5 by $5 \mathrm{~mm}$ excluding appendages, index c. 0.3; margins with 11 appendages of 3 types (type 1: a cluster of 3 at the upper and lower edge; type 2: 3 scattered in between; type 3: 2 appendages in between those of type 1 and 2), base broadly attached; thin, glabrous; appendages of type 1 ovoid, $3.5-4$ by $0.8 \mathrm{~mm}$, abruptly narrowing into a stalk of $0.5-0.7 \mathrm{~mm}$ long, gradually narrowing towards a caudate tip, papillose; appendages of type 2 subulate, $3.2-3.5$ by $0.1-0.2 \mathrm{~mm}$, gradually narrowing into a stalk $0.5-0.8 \mathrm{~mm}$ long, tip acuminate to caudate; appendages of type three intermediate between type 1 and 2. Lip somewhat recurved, elliptic-oblong, c. 3.5 by $2.1 \mathrm{~mm}$, index 1.6-1.7 (all measured without flattening); obtuse, margins entire, glabrous but papillose distally; thick; adaxially concave proximally, the erect margins slightly converging then slightly diverging; with 2 narrow ridges running parallel close to the median line, furrow in between distally converting in a row of irregular pits; surface glabrous; abaxially convex and laterally extending beyond the margins, surface papillose, on the sides with a cluster of ellipsoid vesicles. Column c. $2.5 \mathrm{~mm}$ long, stigma oblong, with a slight swelling at its base, column foot without teeth near the tip. Stelidia porrect, triangular, c. $0.8 \mathrm{~mm}$ long, acute, with a denticulate upper margin, with a distinct, triangular, obtuse tooth which has the front margin folded inwards along the lower margin, and a minute tooth in front of this. Anther abaxially \pm without a crest, surface \pm glabrous, front margin drawn out into a truncate beak with erose margins. Pollinia 4; ovoid, without appendage, the inner c. $0.5 \times$ as long as the outer.

Eponymy - The species is named in honour of Dr. P.A.J. Tindemans for his continuous guidance towards the realisation of the Netherlands Centre for Biodiversity Naturalis.

Colours - Leaves dark green, slightly suffused with purple. Sepals coarsely spotted with reddish purple, the white underground visible only locally. Petals white, spotted reddish purple; appendages almost black. Lip blackish purple with a touch of green along the median line, on the adaxial side.
Habitat \& Ecology — Primary forest, 20-30 m high, on limestone bedrock overlain by $1-2 \mathrm{~m}$ thick layer of red clayey soil, $650-850 \mathrm{~m}$ asl.

Distribution - Papua New Guinea, New Britain.

Note - Uniquely identified within the section by having 3 different types of petal appendages. It shares the adaxially coarsely rugose leaves with $B$. corrugatum J.J.Verm.; next to character above, it differs in having caudate, not obtuse, petal appendages.

Bulbophyllum xyphoglossum J.J.Verm., de Vogel \& A.Vogel, sp. nov. (section Stenochilus) - Fig. 5

A Bulbophyllo werneri et $B$. fallacino floribus maioribus, sepalo medio c. 46 $\mathrm{mm}$ longo contra 24-32 mm longo, labelli parte adaxiali distincte convexa, differt. - Typus: LEI 20080243 (holo LAE; iso L), Papua New Guinea, West New Britain, Asengseng logging area, Upper Au River.

Roots emerging scattered along the rhizome. Rhizome longcreeping, to $8 \mathrm{~mm}$ diam, sections between pseudobulbs up to $9 \mathrm{~cm}$ long, bracts including fibres little persistent. Pseudobulbs ovoid-cylindrical, to 1.2 by $0.9 \mathrm{~cm}$. Leaf with petiole up to $3.5 \mathrm{~cm}$, blade elliptic-oblong, up to 20.5 by $5.8 \mathrm{~cm}$, index (length/width) 3.5-3.6; rounded. Inflorescence c. $12 \mathrm{~cm}$ long, 1-flowered. Peduncle c. $2 \mathrm{~cm}$ long, bracts 3 , the longest c. $15 \mathrm{~mm}$ long. Floral bracts tubular, c. $12 \mathrm{~mm}$, acute. Flowers not opening widely. Pedicel and ovary c. $5.8 \mathrm{~mm}$ long, basal node on a c. $8 \mathrm{~mm}$-long stump. Median sepal recurved, ovate-triangular, c. 46 by $11 \mathrm{~mm}$, index c. 4.2; acute, margins entire, base narrowly attached; rather thick, glabrous. Lateral sepals as the median but oblique, falcate, triangular, c. 42 by $15 \mathrm{~mm}$, index c. 2.8 . Petals recurved, ovate, c. 41 by $7 \mathrm{~mm}$, index 5.8-5.9; acute, margins entire; rather thick, glabrous. Lip recurved, narrowly ovate in general outline, c. 21 by $4.5 \mathrm{~mm}$, index 4.6-4.7, subacute, margins entire; thick, glabrous; adaxially with a cavity proximally, with 2 high ridges converging in front of it and continuing as a high median crest; abaxially with a narrow, rounded median ridge. Column c. $5.5 \mathrm{~mm}$ long, stigma oblong, basal margin somewhat protruding, column foot without teeth. Stelidia porrect, deltoid, c. $1.5 \mathrm{~mm}$ long, rounded, with an antrorse, triangular, tapering, acute tooth along the lower margin. Anther abaxially with a papillose crest, surface otherwise \pm glabrous, front margin drawn out into a concave beak. Pollinia 4; ovoid, without appendage, the inner as long as the outer.

Colours - Sepals and petals pale green, distally green, proximally suffused with red. Lip cream-coloured, greenish distally, finely spotted with red. Column yellow distally.

Habitat \& Ecology — Primary forest, 250-275 m asl.

Distribution - Papua New Guinea, New Britain.

Note - Shares the long lip (compared to the sepals) in combination with an antrorse tooth along the lower margin of the stelidia with B. werneri Schltr., and B. fallacinum J.J.Verm.; differs from both by the distinctly convex adaxial side of the lip, and by the larger flowers (median sepal c. $46 \mathrm{~mm}$ long, vs $24-32 \mathrm{~mm}$ long). In addition, the pseudobulbs are smaller (up to $1.2 \mathrm{~cm}$ long vs $2-5 \mathrm{~cm}$ long), and the rhizome fibres markedly less persistent. Within the section, the last character is shared only with $B$. cheiri Lindl.

Acknowledgements The authors thank Dr. J.F. Veldkamp for preparing the Latin diagnoses. The Netherlands Organization for Scientific Research (NWO, number R 85-383) has partly funded the fieldwork carried out by the second author. The fieldwork was in collaboration with the National Capital Botanical Gardens, Port Moresby. 